\title{
BMJ Global Health Decolonising Global (Public) Health: from Western universalism to Global pluriversalities
}

\author{
Clara Affun-Adegbulu (D) ,1,2 Opemiposi Adegbulu ${ }^{3}$
}

To cite: Affun-Adegbulu C, Adegbulu 0. Decolonising Global (Public) Health: from Western universalism to Global pluriversalities. BMJ Global Health 2020;5:e002947. doi:10.1136/

bmjgh-2020-002947

Handling editor Seye Abimbola

Received 20 May 2020

Revised 2 August 2020

Accepted 3 August 2020
Check for updates

C) Author(s) (or their employer(s)) 2020. Re-use permitted under CC BY-NC. No commercial re-use. See rights and permissions. Published by BMJ.

${ }^{1}$ Department of Public Health, Institute of Tropical Medicine, Antwerpen, Belgium ${ }^{2}$ Department of Political Sciences, University of Antwerp, Antwerpen, Belgium

${ }^{3}$ The Law School, Huddersfield Business School, Centre for Sustainability, Responsibility, Governance and Ethics, University of Huddersfield, Huddersfield, UK

Correspondence to Clara Affun-Adegbulu; caffunadegbulu@gmail.com
'The struggle of our times, one that has hitherto had no name, is the struggle against this overrepresentation of the western bourgeois Man'

$$
\text { -Sylvia Wynter }{ }^{1}
$$

'They(We) are in effect still trapped in a history which they(we) do not understand and until they(we) understand it, they(we) cannot be released from it'

$$
\text { -James Baldwin }{ }^{2}
$$

\section{INTRODUCTION}

A quick Google search using the keywords 'Ebola deaths' produces a series of images showing people in various stages of death and suffering. Two, which appear towards the top, are particularly striking. In one, a woman crawls towards a body, in the other, a man lays motionless on the ground. Both are clearly identifiable. A similar search, this time, using the keywords 'COVID-19 deaths' does not produce comparable results, even though we scrolled much further down the list of results than we had done for Ebola. Why is this the case?

One could answer this question by talking about differences in the places of care and sites of death for the two diseases, the relative newness of COVID-19, or even the algorithms that search engines use. Yet, the truth is, it is hard for us to imagine a situation where such images would ever emerge from a Western country. In our opinion, this points to the larger issue of the dehumanisation of Black and Brown peoples, which is both a symptom and outcome of the hierarchisation of humanity.

At first glance, the field of Global (Public) Health appears to be untouched by this hierarchisation, given that the words 'global' and 'public' connote a universality of humanity and interests. Yet, as we will show, the hierarchisation of humanity is very much an issue in Global (Public) Health.
Summary box

- There is emerging consensus about the need to decolonise Global Health. This is evidenced by the proliferation of seminars, conferences and publications in recent times.

- In many cases, however, the focus and scope of these decolonial efforts tend to be on the Global South and on representation (diversity and equality), practice and the (re)production of knowledge.

- Yet decolonisation is not 'merely about altering the content but also the term on which we are having the conversation'.

- In our opinion, a critical reflection about the very concept of Global Health is indispensable to true decolonisation.

- Global (Public) Health, as currently conceptualised, is based on and inextricably linked to the Eurocentric conception of the (hu)man.

- Global (Public) Health, thus, inevitably (re)produces the processes of othering and dehumanisation which are inherent to this conceptualisation of the (hu)man.

- For Global (Public) Health to become truly decolonised, decolonisation must occur at both the epistemic and ontological levels.

- This requires acknowledging that there are many ways of being and doing, unlearning the universality of being and actively engaging with pluriversalities of being.

\section{ON THE WESTERN UNIVERSAL ONTOLOGY OF GLOBAL (PUBLIC) HEALTH}

The terms 'global' and 'public' which are underpinned by ideas of what is and what it means to be human, ${ }^{1}$ emerged from a Eurocentric imaginary of a world system and a western concept of the human. This conception of the human which can be traced as far back as Grotius' 'of things which belong in common to all men', ${ }^{3}$ in defining who exactly can be considered human and under which circumstances, fails to recognise and/or erases the existence of other peoples, categorisations of humanity and 
geopolitical and historical realities. This has two main consequences.

First is the portrayal and framing of Eurocentric references as neutral and as the norm. These references, guaranteeing themselves through self-erasure, self-appropriation and self-referentiality, present(ed) provincial logic as universal rationality and reject(ed) and constrain(ed) other ways of being and knowledges as peculiar or inferior. ${ }^{1}$

Second and most importantly, in this Eurocentric conception of the human, humanity is hierarchised ${ }^{4}$ and separated into Man and the liminally deviant category of Other, that is, male and female racialised people who are not-humans-as not women/men. ${ }^{1}$ The (western) Man is, in so doing, represented as what is and what it means to be human. This conception of the human, which was central to the colonial venture and supported assertions of moral claims related to the concept of a civilised man, led to processes of dehumanisation which tacitly justified colonialism, imperialism and the civilising project. $^{5}$

Since Global (Public) Health (International Health, Tropical Medicine and Colonial Medicine in its previous incarnations) was, ab initio, created to look after the (western) Man, and further empire expansion and the colonial project. ${ }^{6}$ It is inextricably linked to the Eurocentric conception of the human, and inevitably (re)produces processes of othering and dehumanisation. These processes of dehumanisation and othering have continued beyond the dismantling of many direct colonial administrations, because of the replacement of colonialism by coloniality ${ }^{7}$ i.e. the patterns or matrix of power, born of colonialism, which define and control the economy, culture, knowledge production, body and psyche, and authority, beyond the limits or end of colonialism.

The legacies of these processes of dehumanisation and othering are still being felt in Global (Public) Health, with significant consequences. One example is the racial bias in pain management which is linked to ideas of Black people having 'thicker skin' or less sensitive nerve endings than white people, and being less likely to feel pain. Another is the 'Yellow Peril' trope which others Chinese people and characterises them as carriers of disease. This othering, which was/is evident in the discourses of many in the West, led to hubris and complacency in Western countries, and explains their initial responses to the pandemic. Othering, and in this case, the characterisation of Africa as a diseaseridden continent, is also the reason why many are puzzled by the relatively low COVID-19 case and death rates in Africa. A third example is the dehumanising comment made by Camille Locht during the French TV debate about clinical trials to investigate the use of the BCG vaccine for COVID-19.

\section{TOWARDS PLURIVERSAL AND DECOLONIAL ONTOLOGIES IN GLOBAL (PUBLIC) HEALTH}

There is emerging consensus about the need to decolonise Global Health. This is evidenced by a proliferation of seminars and conferences in recent times, including those organised by the Karolinska Institute, the School of Global Health at the University of Copenhagen, the Harvard TH Chan School of Public Health, the Decolonize Global Health Working Group at the University of Edinburgh and the Duke Decolonizing Global Health student working group at Duke University. One also sees a rise in the number of publications on the subject. ${ }^{8-11}$ In many cases, however, the focus and scope of efforts to decolonise Global Health are on the Global South and on representation (diversity and equality), practice and the (re)production of knowledge. Yet decolonisation is not 'merely about altering the content but also very much the term on which we are having the conversation'. This requires engagement with all the issues 'that maintain the present asymmetrical global relations'. ${ }^{12}$

Global (Public) Health, as currently conceptualised, reflects, produces and reproduces the hierarchies of humanity on which it is based. These hierarchies operate in a way that ensures that the Other cannot be potential subjects of rights and citizenship, define their own interests, self-determine, intervene in the relations of power, or participate in global society. ${ }^{5}$ They also reproduce the various dehumanising structures that infuse the historical and 'geopolitical conditions through which diverse bodies and experiences are socially and politically produced'. ${ }^{13}$ The concept therefore reflects a global racist, heterosexist, capitalist, ableist system which is unresponsive to the realities of many peoples, and therefore serves very few (sections of the Global North).

Since the coloniality of being and the coloniality of knowledge are both central to decolonial theory and integral to the arguments that follow, ${ }^{14}$ the decolonisation of the concept of Global (Public) Health must take place at the epistemic AND ontological levels. Doing this requires addressing the lack of ontological pluralisms in the conceptualisation of humanity (that underpins the concept), redefining what is and what it means to be human and reimagining humanity in the pluriverse. This must necessarily begin with a deconstruction and dismantling of the concept of humanity as currently conceived, the uncoupling of Man from human and the unsettling of the hegemonic western universalist conception of the human which normalises and over-represents the (western bourgeois) Man.

\section{CONCLUSION}

Global (Public) Health is one of those 'labels that lead away from empire and push analysis away from colonial histories and in other directions' ${ }^{15}$ and which focuses on consequences such as health inequalities and inequities rather than their root causes. A critical reflection about the very genealogy of the concept is indispensable to the articulation of a public health that is truly global, and which reflects, satisfies and serves all.

The question is, what does a decolonial investigation of the concept of Global (Public) Health entail in terms of scope, methods and objectives? In our opinion, there can 
be no one-size-fits-all approach, as this would again mean (re) producing the universalism that is inherent to coloniality. Rather than answering this question, therefore, our aim with this commentary is to sound the decolonial alarm on the conceptualisation of Global (Public) Health and bring to light an issue that has been neglected and overlooked for far too long.

Global (Public) Health, as currently conceptualised, presupposes a notion of a universal human subject, yet the concept by virtue of its claims to universality and rejection of that which does not conform to it, is totalitarian. ${ }^{6}$ By pointing out the problematic nature of this, we hope to contribute to moving the debate on coloniality and efforts to decolonise Global (Public) Health, beyond their current and often superficial focus and scope on the Global South and representation, practice and the (re) production of knowledge.

True decolonisation is based on demythologising the origins of the concept, desilencing/legitimising other systems of thoughts, practices and knowledges, and embracing the impossibility of objectivity in knowledge production. ${ }^{12}$ This must necessarily begin with acknowledging that there are many ways of being and doing, unlearning the universality of being and actively engaging with pluriversalities of being. We invite the Global Health community to embark on this journey.

Acknowledgements We thank the anonymous reviewers for their careful reading of our manuscript and their many constructive and insightful comments and suggestions.

Contributors CAA and OA jointly conceived the presented idea. They both drafted the article, revised it and approved the final version to be published. The corresponding author had the final responsibility for submitting the manuscript for publication.

Funding The authors have not declared a specific grant for this research from any funding agency in the public, commercial or not-for-profit sectors.

Competing interests None declared.

Patient consent for publication Not required.

Provenance and peer review Not commissioned; externally peer reviewed.

Data availability statement There are no data in this work.
Open access This is an open access article distributed in accordance with the Creative Commons Attribution Non Commercial (CC BY-NC 4.0) license, which permits others to distribute, remix, adapt, build upon this work non-commercially, and license their derivative works on different terms, provided the original work is properly cited, appropriate credit is given, any changes made indicated, and the use is non-commercial. See: http://creativecommons.org/licenses/by-nc/4.0/.

\section{ORCID iD}

Clara Affun-Adegbulu http://orcid.org/0000-0003-3645-7398

\section{REFERENCES}

1 Wynter S. Unsettling the Coloniality of Being/Power/Truth/Freedom: Towards the Human, After Man, Its Overrepresentation--An Argument. CR: The New Centennial Review 2003;3:257-337.

2 Baldwin J. Collected essays. New York: Library of America, 1998.

3 Grotius H. On the law of war and peace. Paris, 1625.

4 Grosfoguel R. Epistemic Racism/Sexism, Westernized Universities and the Four Genocides/Epistemicides of the Long Sixteenth Century. In: Araújo M, Maeso S, eds. Eurocentrism, racism and knowledge. London: Palgrave Macmillan, 2015: 23-46.

5 Lugones M. Pilgrimages/Peregrinajes. Lanham, MD: Rowman \& Littlefield, 2003.

6 Keller R. Geographies of power, legacies of Mistrust: colonial medicine in the global present. Historical Geography 2006;34:26-48.

7 Quijano A. Coloniality of power and Eurocentrism in Latin America. International Sociology 2000;15:215-32.

8 Sowemimo A. Decolonising Sexual \& Reproductive Health. Disrupted: "The Reproductive Rights Issue", 2020. Available: https:// centreforfeministforeignpolicy.org/journal/2020/3/9/decolonisingsexual-reproductive-health [Accessed 21 Jul 2020].

9 Abimbola S. The foreign gaze: authorship in academic global health. BMJ Glob Health 2019;4:e002068.

10 Pai M. Global health still mimics colonial ways: here's how to break the pattern, 2019. Available: https://theconversation.com/globalhealth-still-mimics-colonial-ways-heres-how-to-break-the-pattern121951 [Accessed 21 Jul 2020].

11 Eichbaum QG, Adams LV, Evert J, et al. Decolonizing global health education. Academic Medicine 2020; Publish Ahead of Print.

12 Rutazibwa O. On babies and bathwater. In: de Jong S, Icaza R, Rutazibwa O, eds. Decolonization and Feminisms in global teaching and learning. 1st edn. London: Routledge, 2018: 158-80.

13 Tuhiwai Smith L. Decolonizing Methodologies Research \& Indigenous Peoples. 2nd edn. London: Zed books (UK), 2012.

14 Fúnez-Flores J, Phillion J. A Political Ontological Approach to Decolonization of Ethnographic Research in Education. In: Sharma $\mathrm{S}$, Lazar A, eds. Rethinking 21st century diversity in teacher preparation, K-12 education, and school policy. Springer: Cham, 2019: 39-54.

15 Stoler A. Imperial debris: on ruins and Ruination. Durham: Duke University Press, 2013. 